\author{
국내산 탈지미강의 영양적 가치 평가와 사료 내 첨가가 \\ 육계 생산성에 미치는 영향 \\ 김은집.안병기.강창원 \\ 건국대학교 축산대학 동물자원연구센터
}

\title{
Evaluation of the Nutritive Value of Local Defatted Rice Bran and Effects of Its Dietary Supplementation on the Performance of Broiler Chicks
}

\author{
E. J. Kim, B. K. Ahn and C. W. Kang \\ Animal Resources Research Center, College of Animal Husbandry, \\ Konkuk University, 1 Hwayang-Dong, Kwangjin-Gu, Seoul 143-701
}

\begin{abstract}
Two experiments were conducted to evaluate the nutritive values of defatted rice bran (DRB) and examine the effects of its dietary supplementation on broiler performances. In Experiment 1, to measure true metabolizable energy (TME), nitrogen corrected true metabolizable energy (TMEn), and true amino acid availability (TAAA), 30g of DRB sample was forced-fed to each of 16 ISA-Brown roosters followed by a $48 \mathrm{~h}$ collection of excreta. The TME and TMEn values for DRB were $2.19 \mathrm{kcal} / \mathrm{g}$ and $2.05 \mathrm{kcal} / \mathrm{g}$, respectively. The mean value of TAAA of the 15 amino acids in DRB was 77.29\%. In Experiment 2, a total of 72 Avian broiler chicks were divided into 4 groups with 3 replicates of 6 birds per replicate, and fed one of the experimental diets containing $0,5,10$ or $15 \%$ of DRB. Feed intake, weight gain, feed conversion rate, and body composition were measured for 3 weeks. Although there were no significant differences $(P \geq 05)$, body weight gain and feed intake of chickens fed a diet containing 15\% DRB were slightly higher than those of the other groups. From these results, it can be concluded that feed formulation using TMEn and TAAA of DRB is an effective method for assuring feed quality and DRB can be supplemented to broiler rations up to $15 \%$ level.
\end{abstract}

(Key words : Defatted rice bran, TMEn, TAAA, Performances, Broiler chicks)

$$
\text { I 서 론 }
$$

쌀(Oryza sativa)은 아시아 국가에서 이용되는 주요 곡물로서 전 세계적으로 567백만 톤이 생 산되며, 이중 약 $91 \%$ 가 아시아에서 생산된다 (FAO, 1998). 미강은 현미를 백미로 도정하는
과정에서 분리되는 부산물로 그 중 일부는 사 료 원료로서 이용되고 있다. 그러나 영양소 조 성의 변이가 다양하며, phytate, trypsin inhibitor, antithiamine factor와 같은 항영양인자가 함유되 어 있어 가금용 원료사료로서의 가치에 대한 인식이 낮다.

\footnotetext{
Corresponding author : Dr. C. W. Kang, Animal Resources Research Center, College of Animal Husbandry, Konkuk University, 1 Hwayang-Dong, Kwangjin-Gu, Seoul 143-701, Korea, TEL : 82-2-450-3669 FAX : 82-2-452-9946
} 
미강은 다른 강피류에 비해 지방의 함유량이 많기 때문에 고온 조건하에서는 산패의 문제를 일으킬 수 있다. 미강 내에는 지방분해효소 (lipolytic enzyme)가 들어 있어 도정 이후에 이 효소가 활성화되기 때문에 유리 지방산 수준이 빠르게 증가하는 것으로 알려져 있다(Farrell, 1994). 또한 미강에서 추출한 미강유는 불포화 지방산의 함량이 높아 'heart oil' 이라 불리며, 음식에 향을 부여하는 특징이 있어 식용으로의 이용을 위한 유지 추출이 증가하고 있다(Taira, 1989). 용매추출 후의 탈지미강은 보존 기간이 늘어나며 단백질 및 광물질 함량이 상대적으 로 증가하는데 비해 조지방 함량이 감소하기 때문에 대사에너지가는 감소한다. 탈지미강의 대사에너지가는 생미강의 약 $75 \%$ 수준이며, 이러한 결과에 비례적으로 사료적 가치도 낮 다(Ravindran과 Blair, 1991).

Kratzer 등 (1974)은 병아리 성장 실험을 통해 유기용매 추출한 탈지미강을 $60 \%$ 이상 첨가하 면 성장저해 영향이 나타난다고 하였으며, Warren과 Farrell (1990)은 두 품종의 탈지미강 을 산란계 사료에 $25 \%$ 수준으로 첨가했을 때 한 품종에서는 대조구 사료와 비교하여 난 생 산성이 감소하였으나 다른 한 품종에서는 차이 가 없었다는 결과를 보고하였다. 그러나 탈지 미강을 이용한 선행연구들은 원료의 일반성분 분석치만을 적용하였다는 점과 배합사료의 가 공 및 농장의 자동급이 설비면에서 볼 때 배합 수준을 비현실적으로 높게 설정하였으며, 탈지 미강의 생체 이용률을 고려한 정밀한 영양소 평가를 근거하여 적정 첨가 수준을 규명한 연 구 자료는 거의 없다. 가축의 생산성 극대화를 위한 배합사료를 제조하려면 원료사료 내에 함 유된 영양소, 즉 에너지 이용률과 아미노산 이 용률을 고려해야 한다(Fernandez 등, 1995).

따라서 본 연구는 국내에서 생산되는 부존사 료자원인 탈지미강의 사료 가치를 생체 이용률 에 근거하여 평가하기 위해 진정 대사에너지 (true metabolizable energy; TME)와 질소보정 진 정대사에너지(nitrogen corrected true metabolizable energy; TMEn), 진정아미노산 이용률(true amino acid availability; TAAA)을 측정하고, 이러한 결
과를 기반으로 육계 사료 내 탈지미강의 적합 한 급여 수준을 구명하고, 에너지 및 아미노산 의 생체 이용률을 기초로 하는 사료 배합의 필 요성을 제시하고자 실행하였다.

\section{재료 및 방법}

실험 I 탈지미강의 영양적 가치 평가

\section{1. 실험동물 및 실험설계}

탈지미강의 사료 원료로서의 가치를 평가하 기 위하여 화학적 분석을 실시하였고 종계 수 탉을 이용하여 에너지 이용률 및 아미노산 이 용률을 평가하였다. 60 주령된 산란종계(ISABrown) 수탉을 체중이 유사한 개체로 선발하여 절식구 8수, 탈지미강 급여구 8수, 총 16수를 임의 배치하여 실시하였다.

실험에 사용된 탈지미강은 국내 사료회사에 서 사용중인 원료를 수집하여 사용하였다.

\section{2. 사양관리}

에너지 및 아미노산 이용률을 측정하기 위해 선발된 종계 수탉은 실험 전 24시간 동안 절식 시켰다. 24 시간 절식 후 $30 \mathrm{~g}$ 의 실험사료를 급 여하고 48시간 동안 배설물을 전량 수집하였 다. 절식구는 실험 전 24시간을 포함하여 실험 기간 중 계속적으로 절식시켰으며 처리구의 배 설물 수집과 같은 시간 동안 같은 방법으로 배 설물을 수집하였으며, 물은 무제한으로 급여하 였다.

\section{3. 조사항목}

\section{(1) 일반성분 분석}

수분, 조단백질, 조섬유, 조지방, 조회분의 분 석은 AOAC (1990) 방법에 따라 실시하였다.

(2) 진정대사에너지(TME) 평가

$\mathrm{TME}$ 를 측정하기 위해서 Sibbald (1976)가 고 안한 강제급여(force-feeding) 방법을 사용하여 
실시하였다. ISA Brown 종계 수탉 16수를 일반 시판 사료로 사육하고, 강제급여를 시작하기 직전에 24시간동안 절식시켰다. 그 후 원료를 각각 $30 \mathrm{~g}$ 씩 강제급여 시킨 후 48시간(Sibbald, 1979) 동안 배설된 모든 배설물을 채취하였다. 또한 기초대사량 측정을 위하여 절식구를 배치 하였다. 채취된 모든 배설물은 깃털과 이물질 등을 제거한 후 $60^{\circ} \mathrm{C}$ 서 24시간 동안 건조시 키고 분쇄하여 분석에 이용하였다.
각 사료와 배설물을 건조 후 bomb calorimeter (Parr 1261)를 사용하여 에너지를 측정하여 대사 에너지를 계산한 후 사료에 기인되지 않은 대사 성 분에너지와 마멸된 장점막, 담즙, 소화액 등의 에너지를 포함한 내인성 뇨에너지를 보정하여 $\mathrm{TME}$ 값을 계산하였다. TMEn은 질소가 체내에서 0 인 상태로 보정하여 체내축적에 의한 배설물의 변이를 줄여준 것으로 본 연구에서는 Titus 등 (1959)이 제안한 8.73을 상수로 하여 계산하였다.

Table 1. Composition of the experimental diets

\begin{tabular}{|c|c|c|c|c|}
\hline \multirow{2}{*}{ Ingredients } & \multirow{2}{*}{$0 \%$} & \multicolumn{3}{|c|}{ Defatted rice bran } \\
\hline & & $5 \%$ & $10 \%$ & $15 \%$ \\
\hline Yellow corn & 58.81 & 55.47 & 50.54 & 50.00 \\
\hline Corn gluten meal & 6.00 & 5.00 & 5.00 & 8.00 \\
\hline Soybean meal & 27.82 & 24.04 & 23.28 & 17.63 \\
\hline India rapeseed meal & 0.00 & 2.00 & 1.41 & 0.00 \\
\hline Limestone & 0.59 & 0.52 & 0.56 & 0.63 \\
\hline Tricalcium posphate & 2.01 & 1.85 & 1.82 & 1.84 \\
\hline Salt & 0.37 & 0.27 & 0.28 & 0.39 \\
\hline Choline chloride & 0.10 & 0.00 & 0.00 & 0.15 \\
\hline Animal fat & 3.37 & 4.77 & 6.00 & 5.28 \\
\hline Lysine $\mathrm{HCl}$ & 0.26 & 0.18 & 0.18 & 0.33 \\
\hline DL-methionine & 0.27 & 0.32 & 0.33 & 0.31 \\
\hline Mineral mix ${ }^{1)}$ & 0.11 & 0.11 & 0.11 & 0.11 \\
\hline Vitamin $\operatorname{mix}^{2}$ ) & 0.12 & 0.12 & 0.12 & 0.12 \\
\hline Salinomysin & 0.10 & 0.10 & 0.10 & 0.10 \\
\hline Sodium bicarbonate & 0.00 & 0.20 & 0.20 & 0.00 \\
\hline Zn bacitracin & 0.10 & 0.10 & 0.05 & 0.05 \\
\hline Defatted rice bran & 0.00 & 5.00 & 10.00 & 15.00 \\
\hline Total & 100.00 & 100.00 & 100.00 & 100.00 \\
\hline \multicolumn{5}{|l|}{ Calculated composition } \\
\hline Dry Matter & 87.63 & 87.70 & 87.76 & 87.76 \\
\hline Crude Protein & 20.00 & 20.00 & 20.00 & 20.00 \\
\hline Ether Extract & 5.73 & 6.69 & 7.44 & 7.78 \\
\hline Crude Fiber & 3.10 & 3.56 & 3.91 & 3.71 \\
\hline Crude Ash & 5.51 & 5.42 & 5.67 & 6.07 \\
\hline $\mathrm{Ca}$ & 0.85 & 0.85 & 0.85 & 0.85 \\
\hline $\mathrm{P}$ & 0.47 & 0.47 & 0.47 & 0.47 \\
\hline TMEn(kcal/kg) & 3080 & 3080 & 3080 & 3080 \\
\hline
\end{tabular}

${ }^{1)}$ Mineral mixture provided following nutrients per kg of diet : Mn, 77mg; Zn, 57.2mg; I, 1.32mg; Se, 0.11mg; $\mathrm{Cu}, 27.5 \mathrm{mg}$.

${ }^{2)}$ Vitamin mixture provided following nutrients per $\mathrm{kg}$ of diet : Vitamin A, 15,600IU; Vitamin $\mathrm{D}_{3}, 3,120 \mathrm{IU}$; Vitamin E, 15.6mg; Vitamin $K_{3}$, 0.91mg; Vitamin $B_{1}$, 1.3mg; Vitamin $B_{12}, 0.026 \mathrm{mg}$; Niacin, 52mg; Oxystat, 65mg; Biotin, 0.039mg; Folacin, 0.39mg; Pyridoxin, 1.3mg; Riboflavin, 13mg; Pantothenic acid, 15.6mg. 
(3) 진정 아미노산 이용률(TAAA) 평가

$\mathrm{TAAA}$ 는 Sibbald (1976)가 제시한 $\mathrm{TME}$ 측정 방법과 동일한 방법을 사용하여 측정하였다 (Likuski와 Dorrell, 1978). 원료와 분 내의 아미 노산 조성은 $6 \mathrm{~N} \mathrm{HCl}$ 용액을 사용하여 $110^{\circ} \mathrm{C}$ 서 22시간 동안 가수분해시킨 다음(Spackman 등, 1958), 아미노산 자동 분석기(Hitachi L$8500 \mathrm{~A}$ )를 이용하여 아미노산 함량을 측정하였 고 Met와 Cys는 가수분해 전에 performic acid 로 산화시킨 후(Moore, 1963) 분석하였다.

실험 $\Pi$ : 사료 내 탈지미강의 첨가가 육계의 생 산성에 미치는 영향

\section{1. 실험동물 및 실험설계}

실험 I |서 측정한 탈지미강의 TMEn과 $\mathrm{TAAA}$ 를 이용하여 배합된 사료를 육계에 급여 함으로써 영양소 이용률에 의한 배합사료의 필 요성을 평가하고 탈지미강의 부존사료자원으로 서의 이용 가능성을 검토하기 위한 목적으로 실시하였다.

Avian 초생추 수평아리를 시판배합사료를 이 용하여 3주간 사육한 후 4주령부터 6주령까지 3 주간 4처리에 3반복 반복당 6수씩 총 72수를 완전 임의배치하여 실시하였다.

\section{2. 실험사료}

실험 I |서 측정한 TMEn과 TAAA를 이용하여 탈지미강 각각 5,10 ,및 $15 \%$ 수준으로 첨가하여 대 두박과 옥수수를 기초로 대조구와 조단백질과 대 사에너지 수준이 동일하도록 배합하였고 실험사 료 내의 모든 영양소 함량을 NRC (1994) 요구량을 충족하거나 상회하는 수준으로 제조하였다. 실험 사료의 배합비는 Table 1에 명시한 바와 같다.

\section{3. 사양관리}

물과 사료는 자유채식시켰고 점등은 종일 점 등으로 하였으며 기타 사양관리는 관행적 방법 에 준하여 실시하였다.

\section{4. 조사항목}

사료섭취량은 급여량과 잔량을 매주 측정하 여 계산하였고 매주 체중을 측정하여 주당 증 체량을 산출하였고 사료 요구율은 사료 섭취량 을 증체량으로 나누어 계산하였다.

\section{5. 통계 분석}

실험에서 얻어진 자료들의 통계 분석은 Statistical Analysis System (SAS, 1985)을 이용하여 실시하였으며 General Linear Model (GLM) Procedure에 의해 처리간 유의성을 검증하였다.

\section{III 결과 및 고찰}

실험 I : 탈지미강의 영양적 가치 평가

\section{1. 일반성분}

Table 2에 탈지미강의 화학적 조성을 나타내었다.

Table 2. Chemical and amino acid compositions of defatted rice bran (as fed basis)

\begin{tabular}{lc}
\hline Chemical composition & Defatted rice bran \\
\hline \hline & $\ldots \ldots \ldots \ldots \ldots \ldots \ldots \ldots \ldots \ldots \ldots \ldots \ldots \ldots \ldots$ \\
Moisture & 10.95 \\
Crude Protein & 18.74 \\
Ether Extract & 8.90 \\
Crude Fiber & 17.39 \\
Ash & 12.26 \\
Amino acids & \\
Val & 0.89 \\
Met & 0.28 \\
Ile & 0.54 \\
Leu & 1.28 \\
Thr & 0.75 \\
Phe & 0.83 \\
His & 0.47 \\
Lys & 0.82 \\
Arg & 1.38 \\
Asp & 1.79 \\
Cys & 0.31 \\
Tyr & 0.58 \\
Ser & 0.89 \\
Glu & 2.45 \\
Ala & 1.16 \\
\hline & \\
\hline
\end{tabular}


탈지미강 내의 수분, 조단백질 및 조지방 함 량은 각각 $10.95 \%, 18.74 \%$ 및 $8.90 \%$ 이었다. 조 섬유 함량은 $17.39 \%$, 조회분 함량은 $12.26 \%$ 인 것으로 나타났다. 사료자원 핸드북(1994)에 명 시된 탈지미강은 수분 함량이 $12.0 \%$, 조단백질 이 $17.7 \%$ 및 조지방이 $2.0 \%$ 로, 본 연구에서는 이러한 자료에 비하여 조단백질 함량이 낮고 대조적으로 조지방 함량은 높은 원료가 이용 되었다. 탈지미강 내 일반성분은 벼의 품종, 미강 원료의 수확 시기 및 가공 방법에 따라 변이가 있다고 알려져 있다(Ravindran과 Blair, 1991).

\section{2. 진정 대사 에너지 평가}

Table 3에는 탈지미강의 TME와 TMEn 값을 나타내었다.

본 연구에서 측정한 탈지미강의 $\mathrm{TME}$ 와 TMEn은 각각 $2.19 \mathrm{kcal} / \mathrm{g}, 2.05 \mathrm{kcal} / \mathrm{g}$ 이었다. 한 등(1976)은 국산 탈지미강의 ME가가 $1.414 \mathrm{kcal} / \mathrm{g}$ 이라고 하였으며, 이와 김(1975)은 탈지미강의 $\mathrm{ME}$ 가가 $1.6 \mathrm{kcal} / \mathrm{g}$ 이라고 보고하였다. 한편 사료 자원 핸드북(1994)에 명시된 탈지미강의 TMEn 값은 $1.940 \mathrm{kcal} / \mathrm{g}$ 으로 본 연구의 결과에 비하여 낮은 경향을 보였다.

Ravindran과 Blair (1991)는 탈지미강의 MEn 가는 생미강의 $75 \%$ 정도 수준이며 가금에서 사료적 가치가 비례적으로 낮다고 하였는데, 이러한 원인은 탈지미강에 지방 함량이 낮기 때문이라고 하였다.

Table 3. Metabolizable energy values of defatted rice bran (dry matter basis) ${ }^{1,2}$

\begin{tabular}{lcc}
\hline & TME & TMEn \\
\hline \hline & $\cdots \cdots \cdots \cdots \cdots \cdots \cdots$ \\
Defatted rice bran & $2.19 \pm 0.09$ & $2.05 \pm 0.08$ \\
\hline${ }^{1)}$ Values are means \pm SE. \\
(2) $\mathrm{TME}$, true metabolizable energy; TMEn, nitrogen \\
corrected true metabolizable energy.
\end{tabular}

\section{3. 아미노산 조성과 TAAA}

탈지미강의 아미노산 조성과 종계 수탉을 이
용하여 측정한 TAAA에 대한 결과를 Table 4에 명시하였다.

탈지미강 내의 Met 함량은 $0.28 \%$ 로 식물성 박류 내의 Met 함량 보다 훨씬 낮았다. 김 등 (1995)은 국산대두박에서 Met이 0.55\%였고, 면 실박에서 $0.55 \%$, 아마박에서는 $0.57 \%$ 라고 하였 다. 탈지미강 내의 Lys 함량은 $0.82 \%$ 로 대두박 에서 Lys 함량이 $3.46 \%$ 였다고 보고한 Cave (1988)의 결과에 비해 낮았지만, Leu과 $\mathrm{Arg}$ 은 각각 $1.28 \%$ 및 $1.38 \%$ 가 함유되었다.

가금 사료에서 TAAA은 가축에 의해 이용되 지 않은 사료 내 아미노산에서 절식 시나 혹은 무단백 사료 급여 시 발생하는 내인성 아미노 산을 제외시킨 아미노산 이용률을 말하는데, 배설물 내의 미생물에 의한 아미노산 변화 (Kessler 등, 1981; Parsons 등, 1981) 그리고 적 은 양을 급여 시에 절식구와 급여구에서 동일 하지 않다는 문제(McNab와 Fisher, 1981)가 있 지만, 다른 방법에 비해 분석비용이 저렴하고 방법이 용이하므로(Engster 등, 1985) 여러 연구 자들에게 이용되어 왔다. 탈지미강 내의 각각 의 아미노산의 이용률을 보면 $\mathrm{Val}$ 과 Ile을 제외

Table 4. True amino acid availability of defatted rice bran (dry matter basis)

\begin{tabular}{cc}
\hline & Availability $^{1)}$ \\
\hline \hline Val & $\ldots \ldots \ldots \ldots \ldots \ldots \ldots \ldots \ldots \ldots \ldots \ldots \ldots \ldots \ldots \ldots \ldots$ \\
Met & $64.19 \pm 2.59$ \\
Ile & $80.28 \pm 1.66$ \\
Leu & $59.89 \pm 3.05$ \\
Thr & $74.66 \pm 1.91$ \\
Phe & $77.20 \pm 1.81$ \\
His & $74.80 \pm 1.98$ \\
Lys & $80.23 \pm 1.51$ \\
Arg & $74.61 \pm 1.93$ \\
Asp & $88.76 \pm 0.92$ \\
Cys & $76.99 \pm 1.68$ \\
Tyr & $83.73 \pm 1.78$ \\
Ser & $78.73 \pm 1.81$ \\
Glu & $82.66 \pm 1.54$ \\
Ala & $84.04 \pm 1.29$ \\
Mean & $78.62 \pm 1.61$ \\
\hline
\end{tabular}

${ }^{1)}$ Values are means $\pm \mathrm{SE}$. 
한 모든 아미노산의 이용률이 $70 \%$ 를 상회하였 다. Met와 Lys의 생체 이용률은 각각 $80.28 \%$ 및 74.61\%로, 특히 식물성 박류에서 Lys의 이 용률이 크게 떨어지는 것을 감안하면 탈지미강 내의 Lys 이용률은 상대적으로 높은 것으로 보 여진다. 탈지미강 내의 15 개 아미노산의 평균 이용률은 77.29\%로 Cave (1988)가 보고한 대두 박, 옥수수 글루텐, 옥수수의 이용률 (93.89\%에 서 $96.03 \%)$ 에 비해서는 낮았다.

탈지미강의 아미노산 이용률을 조사한 연구 는 거의 없지만 Nitis (1973)는 미강의 아미노산 소화율이 대두박과 유사하거나 약간 낮다는 결 과를 보고하였다. Warren과 Farrell (1991)은 탈 지미강의 아미노산 이용률이 생미강에 비해 낮 다고 하였는데 이러한 결과가 유지 함량에 의 한 것이라기보다는 품종의 차이일 수 있다고 하였다.

실험 $\Pi$ : 사료 내 탈지미강의 첨가가 육계의 생 산성에 미치는 영향

탈지미강을 다양한 수준으로 첨가한 실험 사 료를 육계에 급여했을 때 사료 섭취량, 주당 증체량 및 사료 요구율에 미치는 영향에 대한 결과를 Table 5에 명시하였다.

탈지미강 $15 \%$ 첨가구에서 $139.6 \mathrm{~g}$ 으로 일당 사료 섭취량이 가장 높았으나 탈지미강 $5 \%$ 및 $10 \%$ 첨가구에서는 각각 $124.4 \mathrm{~g}, 128.6 \mathrm{~g}$ 으로, 대 조구의 $135.8 \mathrm{~g}$ 에 비해 다소 낮은 경향을 보였 다. Zombade와 Ichhponani (1983)는 탈지미강을 $20 \%$ 첨가한 실험사료를 육계에 급여했을 때 대조구에 비해 사료섭취량이 유의하게 증가하 였다고 보고하였는데, Adrizal 등(1996)은 탈지
미강을 $22.5 \%$ 수준으로 첨가하여도 사료 섭취 량에 차이가 없었다고 하였다. 선행연구에서의 사료섭취량의 차이는 탈지미강 첨가사료 내의 대사에너지가 동일하게 맞추어지지 않았기 때 문이며, 따라서 탈지미강 첨가 시에 대사에너 지를 유사하게 조절하는 경우 사료섭취량에서 큰 차이를 보이지 않을 것으로 사료된다.

본 연구에서는 탈지미강을 첨가한 모든 실험 구에서 주당 증체량이 대조구에 비해 낮은 결 과가 관찰되었다. 탈지미강 $5 \%$ 첨가구에서의 주당 증체량은 $508.2 \mathrm{~g}$ 으로 대조구의 $532.2 \mathrm{~g}$ 에 비해 약 $24 \mathrm{~g}$ 정도 증체가 낮은 것으로 나타났 으나 통계적인 유의차는 인정되지 않았다. 특 히 탈지미강 $15 \%$ 첨가구는 사료섭취량이 가장 많았으면서도 대조구에 비해 주당 증체량이 더 낮은 것으로 나타났다. 사료섭취량 및 증체량 의 차이에 대해서 설명이 어려우며, 추후 연구 를 통해 영양소 소화율에 대한 조사와 탈지미 강 내의 항영양인자에 대한 분석이 필요할 것 으로 사료된다.

탈지미강을 이용한 연구에서 모든 실험사료 를 영양소 함량이 균일하도록 배합했을 때 성 장률과 사료요구율은 원료의 수확 방법과 첨가 수준에 따라 다소 상이하게 나타났다. Kratzer 등(1974)은 병아리 성장 실험을 통해 hexane과 methanol과 같은 유기용매 추출한 탈지미강을 $60 \%$ 이상 첨가하면 성장이 저해되었으며, Warren과 Farrell (1990)은 두 품종의 탈지미강 을 산란계 사료에 $25 \%$ 수준으로 첨가했을 때 한 품종에서는 대조구 사료와 비교하여 난 생 산성이 감소하였으나 다른 한 품종에서는 차이 가 없었다는 결과를 발표하였다. 대조적으로 Warren과 Farrell (1990)은 탈지미강 첨가 수준

Table 5. Effects of dietary defatted rice bran on feed intake, weight gain and feed conversion rate in broiler chickens ${ }^{1)}$

\begin{tabular}{lcccc}
\hline & \multirow{2}{*}{ Control } & \multicolumn{4}{c}{ Defatted rice bran } \\
\cline { 3 - 5 } & & $5 \%$ & $10 \%$ & $15 \%$ \\
\hline \hline Feed intake, g/d/bird & $135.8 \pm 4.6$ & $124.4 \pm 1.2$ & $128.6 \pm 1.7$ & $138.6 \pm 47.7$ \\
Weight gain, g/bird & $532.2 \pm 7.0$ & $508.2 \pm 12.0$ & $518.8 \pm 18.7$ & $510.1 \pm 20.8$ \\
Feed conversion rate ${ }^{2)}$ & $1.78 \pm 0.03$ & $1.75 \pm 0.03$ & $1.82 \pm 0.08$ & $1.81 \pm 0.08$ \\
\hline
\end{tabular}

1) Values are means \pm SE.
Feed conversion rate $=$ feed intake/weight gain. 
을 $7 \%$ 에서 $21 \%$ 로 하여 3 일령에서 13 일령까지 육계에 급여했을 때 성장률과 사료요구율이 개 선되었다고 하였다. 따라서 선행연구 결과들을 통해서도 탈지미강의 첨가가 생산성에 미치는 영향 및 이의 적정 첨가 수준의 결정은 이용하 는 원료의 품질에 따라 다소 달라질 것으로 사 료된다.

탈지미강 $10 \%$ 및 $15 \%$ 첨가구에서는 대조구 에 비해 사료요구율이 더 높은 것으로 나타났 지만 탈지미강 $5 \%$ 첨가구에서는 1.75 로 대조구 의 1.78 에 비해 사료요구율이 약간 개선되는 결과가 얻어졌다. 탈지미강 $5 \%$ 첨가구에서 사 료요구율이 가장 낮게 나타난 결과는 증체량이 높아서가 아니라 사료 섭취량이 모든 처리구 중에 가장 낮았다는 점에 기인하였다.

Adrizal 등(1996)은 육계를 공시한 연구에서 옥수수 - 대두박 위주의 대조구 사료와 대사에 너지 및 영양소 함량이 동일한 사료를 제조 시 에 탈지미강을 $22.5 \%$ 수준으로 높여 급여하더 라도 처리구간에 사료요구율은 차이가 없었다 고 하였다. 따라서 탈지미강은 가금에 원료사 료로서 이용하기 전에 품질평가를 정확하게 한 다면 부존자원의 사료화를 위한 적합한 원료사 료로 이용할 수 있을 것으로 사료된다.

$$
\text { IV 요 약 }
$$

본 연구는 탈지미강의 부존사료원료로써의 영양적 가치 평가와 사료 내에 첨가수준을 달 리했을 때 육계의 생산성에 미치는 영향을 구 명하기 위한 목적으로 수행되었다.

실험 I |서는 절식구 8수, 탈지미강 급여구 8 수, 총 16 수의 종계 수탉을 공시하여 강제급 여에 의해 탈지미강의 TME, TMEn 및 TAAA 를 평가하였다. 탈지미강의 TME와 TMEn은 건 물 기준으로 각각 $2.19 \mathrm{kcal} / \mathrm{g}, 2.05 \mathrm{kcal} / \mathrm{g}$ 이었으 며, 15 개 아미노산의 평균 생체이용률은 $77.29 \%$ 로 나타났다.

실험 ㅍ |서는 옥수수와 대두박 위주의 대조 구 사료와 탈지미강을 $5 \%, 10 \%$ 및 $15 \%$ 수준 으로 첨가한 실험사료를 총 72 수의 육계 (4처 리, 3반복, 반복당 6수)에 3주간 급여하였다. 사
료섭취량은 탈지미강 $15 \%$ 첨가구에서 가장 높 았지만 처리간에 통계적인 유의차는 없었다. 주당 증체량은 탈지미강을 여러 수준으로 첨가 한 처리구에 비해 대조구에서 가장 높은 것으 로 나타났다. 탈지미강 $10 \%$ 및 $15 \%$ 첨가구에 서는 대조구에 비해 약간 높아졌으나 통계적인 유의차는 인정되지 않았다. 탈지미강 $5 \%$ 첨가 구에서 통계적인 유의차는 나타나지 않았지만 사료요구율이 가장 낮은 것으로 나타났다.

본 실험에서는 사료 원료의 정확한 품질 평 가 및 생체이용률을 근거로 사료를 배합했을 때 항영양인자가 함유되어 있지 않는 한 사료 의 품질저하를 막을 수 있었고, 탈지미강 역시 가금 사료 내에 다양한 수준으로 첨가하여 부 존사료원료로써 이용할 수 있다는 결과가 시사 되었다.

(색인어 : 탈지미강, TMEn, TAAA, 생산성, 육계)

\section{$\mathrm{V}$ 인 용 문 헌}

1. Adrizal, Palo P. E. and Sell J. L. 1996. Utilization of defatted rice bran by broiler chickens. Poultry Sci., 75:1012.

2. Association of Official Analytical Chemists. 1990. Official Methods of Analysis of the Association of Official Analytical Chemists, 15th ed.

3. Cave, N. A. 1988. Bioavailability of amino acids in plant feedstuffs determined by in vitro digestion, chick growth assay, and true amino acid availability methods. Poultry Sci., 67:78.

4. Engster, H. M., Cave, N. A., Likuski, H., McNab, J. M., Parsons, C. A. and Pfaff, P. E. 1985. A collaborative study to evaluate a precision-fed rooster assay for true amino acid availability in feed ingredients. Poultry Sci., 64:487.

5. FAO. 1998. FAO Production Yearbook, Vol.41, Food and Agriculture Organization of the United Nations, Rome.

6. Farrell, D. J. 1994. Utilization of rice bran in diets for domestic fowl and duckling. World's Poultly Sci. J., 50:115.

7. Fernandez, S. R., Zhang, Y. and Parsons, C. M. 1995. Dietary formulation with cottonseed meal on a total amino acid versus a digestible amino acid basis. Poultry Sci., 74:1168. 
8. Kessler, J. W., Nguyen, T. H. and Thomas, O. P. 1981. The amino acid excretion values in intact and cecectomized negative control roosters used for determining metabolic plus endogenous urinary losses. Poultry Sci., 60:1576.

9. Kratzer, F. H., Earl, L. and Chlaravanont, C. 1974. Factors influencing the feeding value of rice bran for chickens. Poultry Sci., 53:1795.

10. Likuski, H. J. A. and Dorrell, H. G. 1978. A bioassay for rapid determinations of amino acid availability values. Poultry Sci., 57:1658.

11. McNab, J. M. and Fisher, C. 1981. The choice between apparent and true metabolizable energy system -recent evidence. pp 45-55 : in Proc. 3rd. European Symposium on Poultry Nutrition, Edinburgh, U.K.

12. Moore, S. 1963. On the determination of cysteine as cysteic acid. J. Biol. Chem., 238:235.

13. National Research Council. 1994. Nutrient Requirements of Poultry. 9th rev. ed. National Academic Press, Washington, DC.

14. Nitis, I. M. 1973. Nutritional evaluation of copra meal and rice pollard for growing chicks. Ph.D. Thesis, University of New England, Armidale.

15. Parsons, C. M., Potter. L. M. and Brown R. D. Jr. 1981. True metabolizable energy and amino acid digestibility of dehulled soybean meal. Poultry Sci., 60:2687.

16. Ravindran, V. and Blair, R. 1991. Feed resources for poultry production in Asia and the Pacific region. 1. Energy sources. World's Poultly Sci. J., 47:213.

17. SAS. 1985. SAS User's guide, Statistical Analysis System Inst. Inc. Cary NC.

18. Sibbald, I. R. 1976. A bioassay for true metabolizable energy in feeding-stuffs. Poultry Sci., 55:303.

19. Sibbald, I. R. 1979. The effect of the duration of the excreta collection period on the true metabolizable energy values of feedingstuffs with slow rates of passage. Poultry Sci., 58:896.

20. Spackman, D. H., Stein, W. H. and Moore, S. 1958. Automatic recording apparatus for use in the chromatography of amino acids. Anal. Chem., 30:1190.

21. Taira, H. 1989. Fatty acid composition of Indica-and Japonica-types of rice bran and milled rice. J. Am. Oil. Chem. Soc., 66:1326.

22. Titus, H. W., Mehring, A. L., Johnson, D. Jr., Nesbitt, L. L. and Tomas, T. 1959. An evaluation of MCF (micro-cel-fat), a new type of fat product. Poultry Sci., 38:1114.

23. Warren, B. E. and Farrell, D. J. 1990. The nutritive value of full fat and defatted Australian rice bran. 1. Chemical compositon. Anim. Feed Sci. Technol., 27:219.

24. Warren, B. E. and Farrell, D. J. 1991. The nutritive value of full fat and defatted Australian rice bran. 5. The apparent retention of minerals and apparent digestibility of amino acids in chickens and adult cockerels fitted with ileal cannulae. Anim. Feed Sci. Technol., 34:323.

25. Zombade, S. S. and Ichhponani, J. S. 1983. Nutritive value of raw, parboiled, stabilized, and deoiled rice bran for growing chicks. J. Sci. Food Agric., 34:783.

26. 김대성, 한인규, 최윤재, 이찬호, 김진욱, 신인수. 1995. 가금에 있어서 특정원료사료의 진정 아미 노산 이용률 측정. 한축지 19:12.

27. 사료자원 핸드북. 1994. 강피류 사료 $\mathrm{pp} 112$.

28. 이남형, 김춘수. 1975. 브로일러 초생추에 있어서 강피류 사료의 대사에너지 측정에 관한 연구 (제 4보), 한축지. 17:228.

29. 한인규, 백인기, 하종규. 1976. 국산박류의 사료적 가치에 관한 연구. IV 육성돈에 대한 국산박류의 사료가치 비교시험. 한축지. 18:420.

(접수일자 : 2003. 4. 15. / 채택일자 : 2003. 7. 8. ) 